\section{Moderating role of LMX and proactive coping in the relationship between learning value of the job and employability enhancement among academic staff employees}

Moderating role of LMX and proactive coping

\author{
Beatrice Van der Heijden
}

Institute for Management Research, Radboud University, Nijmegen, The Netherlands; Open University of The Netherlands, Heerlen, The Netherlands;

Ghent University, Ghent, Belgium;

Hubei University, Wuhan, China and

Kingston University, London, UK, and

\section{Daniel Spurk}

Department of Work and Organizational Psychology, Institute of Psychology, University of Bern, Bern, Switzerland

\begin{abstract}
Purpose - Building upon a competence-based employability model and a social exchange and proactive perspective, the purpose of this paper is to investigate the relationship between learning value of the job and employability among academic staff employees. Moreover, this study also examined whether this relationship was moderated by leader-member exchange (LMX) and a proactive coping style.

Design/methodology/approach - An online self-report questionnaire with thoroughly validated measures was distributed among academic staff employees $(n=139)$.

Findings - The results partially supported the specific study assumptions. Concrete, learning value of the job was positively related to anticipation and optimization, corporate sense and balance. LMX moderated the relationship between learning value of the job, on the one hand, and all employability dimensions, on the other hand. However, proactive coping only moderated the relationship with anticipation and optimization, flexibility and balance. In all cases, under the condition of high moderator variable levels, the relationship became stronger. Originality/value - This study extends past employability research by applying an interactionist perspective (person: proactive coping style, context: LMX and learning value of the job) approach for explaining employability enhancement. The results of this scholarly work provide useful insights for stimulating future career development and growth, which is of upmost importance in nowadays' labor markets.
\end{abstract}

Keywords Employability, Leader-member exchange, Academic staff, Learning value, Proactive coping style Paper type Research paper

\section{Introduction}

Self-perceived employability, also known as career potential (Van der Heijde and Van der Heijden, 2006), is at the core of a positive process that leads to optimal employee functioning (Vanhercke et al., 2014). Furthermore, protecting one's life-long employability comprises a key

(C) Beatrice Van der Heijden and Daniel Spurk. Published by Emerald Publishing Limited. This article is published under the Creative Commons Attribution (CC BY 4.0) licence. Anyone may reproduce, distribute, translate and create derivative works of this article (for both commercial and non-commercial purposes), subject to full attribution to the original publication and authors. The full terms of this licence may be seen at http://creativecommons.org/licences/by/4.0/legalcode
Received 29 September 2018 Revised 18 February 2019 19 March 2019 Accepted 21 March 2019 
CDI

24,2

164

characteristic of survival in today's labor markets (Forrier et al., 2015; Fugate et al., 2004; Van der Heijden, De Lange, Demerouti and Van der Heijde, 2009). The combination of the ever-increasing speed in developments (e.g. new production concepts and new technology) and expanded globalization with increased demands on productivity, creativity and flexibility, requires that most employees update their competencies across their work life (Berntson et al., 2006; Nazar and Van der Heijden, 2014; Van der Heijde and Van der Heijden, 2014). Besides employees' own initiatives and efforts, organizations are also expected to provide opportunities for development, and to offer a greater variation in tasks and jobs that may enhance the employability of their employees (Thijssen et al., 2008; Van Harten et al., 2016).

Employability enhancement occurs when workers are provided with ample learning experiences that enable the practice and extension of their capabilities (Pulakos et al., 2000; Van der Heijden and Bakker, 2011) in order to maintain, cultivate and further develop fundamental qualifications (Brown et al., 2001). Therefore, we posit that it is of utmost importance that a job has a high learning value, meaning that it is challenging and comprises tasks and responsibilities that are optimally broad and complex, and involves novelty, autonomy and the possibility to explore alternative strategies and solutions (Amabile et al., 1996). As such, a job with a high learning value is considered to be a nutrient for building up new knowledge, skills, expertise and competencies (Boerlijst et al., 1993; Van der Heijden and Bakker, 2011).

Given the abovementioned developments within the contemporary labor market, the need for a better understanding of the role that the learning value of an employee's job can play for enhancing employability is more urgent than ever. However, up to now, most empirical studies on training or learning and employability have limited their investigation to antecedents of employability enhancement related to participation in formal training outside of the job, thereby ignoring other aspects of learning (Groot and Maassen van den Brink, 2000; Sanders and De Grip, 2004). Previous research has already indicated that the degree of challenge or complexity in one's job is positively related to employability enhancement (Holman et al., 2001; Van Emmerik et al., 2011). However, more scholarly work is needed in order to better understand the added value of the learning and development opportunities of the job itself (Jacobs and Jones, 1995), and the potential boundary conditions under which the learning value of one's job is specifically beneficial.

Therefore, in line with Clarke and Patrickson (2008), who stated that employability should be a shared responsibility of both employer and employee, we adopted an interactionist perspective (Endler and Magnusson, 1976; Lewin, 1935) for testing our employability enhancement model (see also Nauta et al., 2009; Veld et al., 2015). More specifically, we have incorporated the impact of one contextual characteristic (i.e. leader-member exchange (LMX)), and one personal characteristic (i.e. employee proactive coping style) as possible moderators in the relationship between learning value of the job and the worker's employability. In sum, this study responds to previous calls for a greater consideration of the interaction between person and context, to prevent fragmentation of the scholarly work in this field (for instance, see Cappelli and Sherer, 1991; De Vos et al., 2011, 2018; Mowday and Sutton, 1993).

Although past research has established a principal linkage between learning value of the job and employability (Van der Heijden and Bakker, 2011; Van der Klink et al., 2014; Van der Heijden et al., 2016), to the best of our knowledge, this study is the first to investigate the influence of LMX on the learning value of the job-employability linkage. Besides adding knowledge about boundary conditions for the learning value of the jobemployability link, this study also extends relatively scarce research on LMX-related moderation models (Martin et al., 2016). Such knowledge, in relation to career-related outcomes, would inform career and organizational research, as well as career counseling and HRM practices. Moreover, this study is the first to investigate the possible moderating role of an employee proactive coping style. The recent increase in interest in proactivity has emerged following its importance in many modern, dynamic and global organizations 
(Den Hartog and Belschak, 2007; Thomas et al., 2010). If individuals wish to ensure their employability in both the internal and external labor market, they should actively engage in a range of career-self management behaviors (King, 2004; Kuijpers and Scheerens, 2006; Sturges et al., 2010). More specifically, individuals should proactively manage their workplace experiences (e.g. optimally profit from the learning value of their job), with the goal to best capitalize on environmental resources (Fuller and Marler, 2009).

Against this background, the first purpose of the present study is to look into the predictive validity of the employee's learning value of the job in light of employability. As such, this study contributes to the investigation of appropriate dimensions of sustainable careers (Van der Heijden and De Vos, 2015) by examining possible antecedents of perceived employability against the theoretical frameworks of Job Demands-Resources (e.g. Bakker and Demerouti, 2007; Demerouti et al., 2001) and conservation of resources (COR) (Hobfoll, 1988, 1989). Moreover, we aim to better understand the extent to which the exchange relationship between an employee and a direct supervisor may strengthen this relationship, and/or whether it is a matter of the employee's own coping style that determines the association. That is to say, we intend to explore the role of supervisors and employees as main stakeholders in the employability enhancement process.

Finally, this study helps to overcome the North American bias in career research (e.g. Spurk et al., 2019; Sullivan and Baruch, 2009) by using a Dutch sample of academic staff. Traditionally, most academic careers have followed the so-called tenure track system in a relatively rigid hierarchy, and have consisted of long-term employment relationships (Baruch and Hall, 2004). In some countries (e.g. France and Spain), this traditional career path is still prevalent, whereas in many other countries, such as the UK (Gosling, 2009), the Middle East (Gholifar et al., 2011), the USA (Schuster and Finkelstein, 2006), and the Netherlands (De Weert, 2001), a professional mobility pattern is more often observed (Griffin et al., 2005). Moreover, in the Netherlands, the proportion of academic staff in permanent positions has fallen, and the proportion of those working on temporary contracts has risen (VSNU, 2015). As a result, academic staff are more often confronted with job insecurity and concerned about continuous updating of knowledge and skills because further employability development is urgent (Rowold and Schilling, 2006).

\section{Theoretical framework}

\section{Learning value of the job and employability}

Job resources, of which jobs with a high learning value are endowed, are important predictors for enhancing positive work outcomes (see the job demands-resources framework (JD-R); Bakker and Demerouti, 2007; Demerouti et al., 2001). They can play an intrinsic or extrinsic motivational role (Bakker, 2011): for instance, an intrinsic role by allowing employees to further grow in their field, and an extrinsic role by achieving work goals. In the past, the main approach to fostering a worker's career potential was to focus on more or less formal classroom-based learning. Today, formal job qualifications are not enough to protect one's employability (see also Tomlinson, 2008). Individuals also need to possess sound practical knowledge, skills and social relations that have been acquired through work experience (Cheetham and Chivers, 2001; Eraut, 2004; Evers et al., 2011) in order to survive in the current labor market (Siivonen and Isopahkala-Bouret, 2016).

Learning entails "a relatively permanent change in knowledge or skill produced by experience" (Weiss, 1990, p. 173), and therefore jobs should urge employees to invest in further professional development, and to actively use different types of work-related competencies, knowledge and skills (Hornung et al., 2010). The learning value of a job refers to the extent to which tasks and responsibilities enable the employee to elaborate on his or her existing arsenal of occupational knowledge and skills (Van der Heijden and Bakker, 2011, p. 234). A job with a high learning value contains tasks and responsibilities that are
Moderating role of LMX and proactive coping 
CDI

24,2

broad enough, and that require and allow the employee to explore novel and alternative strategies and solutions (Amabile et al., 1996; Maurer et al., 2003).

Following the JD-R framework (Bakker and Demerouti, 2007; Demerouti et al., 2001), we argue that enhancement of workers' employability can be furthered when they go through challenging learning experiences, and if their job allows them to explore new things (see also Pulakos et al., 2000). In other words, renewing one's knowledge and skills (competencies) is seen as the key for employability management (De Pater et al., 2009; De Vos and Van der Heijden, 2015).

Earlier empirical evidence has shown that having a job with a high learning value contributes to employee development (Berings et al., 2008; DeRue and Wellman, 2009; Dragoni et al., 2009), and to self-perceived employability (Van der Heijden, Boon, Van der Klink and Meijs, 2009; Van der Heijden, De Lange, Demerouti and Van der Heijde, 2009). Moreover, employee flexibility - being an important ingredient of employability - has been found to be positively influenced by one's job complexity (Kohn and Schooler, 1982; Van der Heijden and Bakker, 2011). Therefore, and based on the previous outline, we formulated the following hypothesis:

H1. Learning value of the job and workers' employability is positively associated.

\section{The moderating role of LMX in the relationship between learning value of the job and employability}

One of the most influential frameworks in the area of leadership is the LMX, or the quality of the employee's relationship with his/her leader framework, which has emerged as an important tool in predicting a wide range of outcome variables (Gooty and Yammarino, 2016; Martin et al., 2016). The interaction between employee and supervisor (LMX) lies at the heart of social exchange theory (see Blau, 1964; Cropanzano and Mitchell, 2005; Wang et al., 2005). Supervisor ratings of follower job performance are the most frequently studied outcome of LMX at the individual level (see Dulebohn et al., 2012 for an overview).

Following this line of thought, it is conceivable that high-quality LMX, characterized by followers being in supportive relationships with their leaders, has an impact on the learning value of the job-employability linkage. In particular, building upon the COR theory (Hobfoll, 1988, 1989), we argue that under the condition of high-quality LMX, supervisors facilitate workers' employability enhancement or career potential (see also Raghuram et al., 2017), and will provide them with benefits helpful for further development of their competencies. The provided benefits (e.g. rich communication, increased support and more attractive work roles) that are given to employees in high-quality LMX relationships boost their existing resources (see also Harris et al., 2011; Nielsen et al., 2008), and hence LMX can be seen as a contextual resource within the COR framework. Theoretically, such a contextual resource entails the ability to facilitate the use of other resources (Hobfoll, 1989), such as learning value of the job, when obtaining valued outcomes such as employability.

Specifically, employees who are better able to obtain resources required for high-quality job performance, or whose supervisors favor them, are likely to invest more effort into their tasks and duties, and can rely on their leaders if they are in need of support and guidance in difficult and unclear situations (Gerstner and Day, 1997; Gooty and Yammarino, 2016). Moreover, high-quality LMX - reflected in more support, acceptance and security - can empower and motivate employees to experiment with and try out new things that are provided in a job with a high learning value, which is then of benefit to their professional development (see also Yizhong et al., 2019). Expressed differently, only having a job with a high learning value is less beneficial in comparison to having such a job combined with a high LMX quality because it enables a person to make the best of the job, due to necessary security, trust and empowerment. 
On top of this, employees with high-quality LMX relationships obviously value this relationship, and - following social exchange theory (Cropanzano and Mitchell, 2005) - are inclined to reciprocate to their supervisors by responding positively to demanding work experiences (Kamdar and Van Dyne, 2007). From this perspective, doing one's best and actively working with the abundant opportunities provided by a high learning value job are ways of reciprocating under the conditions of a high LMX relationship. Hence, employees are motivated to signal to their supervisor that they indeed are drawing upon the provided resources, and are able to pay back trust and rewards provided by the supervisor.

Finally, there is empirical evidence that employees working in the same organization differ in terms of their perceptions regarding the amount of investments the organization is willing to make (Kuvaas and Dysvik, 2009). Given the key role the immediate supervisor can play in shaping the employees' evaluations of HRM practices (Kuvaas and Dysvik, 2010), we also argue that LMX may moderate the impact of the employee's learning value of the job on his/her employability. Also, the amount of LMX that employees report is assumed to have implications for their experience regarding the amount of support for career development that they receive (for instance, in terms of time allocated for learning, autonomy and a safe climate, wherein one can make mistakes while learning), and on their perceptions of stimulating developmental HR measures. High-quality LMX employees enjoy leadership techniques that focus on and support developmental HR practices (Keller and Dansereau, 1995). By contrast, employees low in LMX quality relationships are subject to supervisory techniques that are predominantly aimed at maintenance HR practices (see also Veth et al., 2015). As a result, the first category of workers (high-quality LMX) is supposed to benefit more from a job with a high learning value (compared to their counterparts, who report less LMX) because they receive the necessary resources, time and autonomy to draw upon the provided learning value, which is also reflected in well-fitting HR practices. Based on the outline given above, the following moderation hypothesis was developed:

H2. The relationship between learning value of the job and workers' employability is moderated by LMX. With higher LMX quality, the relationship is assumed to be more strongly positive.

\section{The moderating role of a proactive coping style in the relationship between learning value of the job and employability}

As this study adopts an interactionist perspective (Endler and Magnusson, 1976; Lewin, 1935), in addition to LMX (a contextual factor), we incorporate the impact of a proactive coping style (a personal characteristic) in our study as well. In line with recently addressed research challenges that were aimed at extending the JD-R framework (Bakker and Demerouti, 2007; Demerouti et al., 2001), we argue that next to the important role that management should play, employees themselves should also take responsibility for mobilizing their own job resources (Demerouti and Bakker, 2011; see also Bakker et al., 2012 on the association between proactive personality and job crafting).

A proactive coping style is a helpful strategy for dealing with stressful events, and is reflected in sound processes of personal quality of life management and self-regulatory goal attainment. It refers to one's tendency to envision and prepare in light of upcoming life challenges (Schwarzer and Taubert, 2002); including current challenges that are related to one's needed job qualifications (Erdogan and Bauer, 2005; Parker et al., 2010). Specifically, first, proactive coping facilitates promotion of challenging goals and personal growth. It is future oriented and consists of efforts to build up general resources, such as self-efficacy (Bandura, 1992) and social support. Second, it implies that people have a vision, and during difficult situations, they adopt goal management strategies instead of risk management ones. Third, they perceive difficult situations as challenging and stimulating, and in that sense, the motivation for proactive coping is positive (Greenglass, 2002).
Moderating role of LMX and proactive coping 
CDI

24,2

168

Hobfoll $(1988,1989)$, in his COR theory, argued that people aim to keep those resources they already possess, protect resources when threatened and work to obtain resources they do not yet have. COR theory suggests that various types of resources aggregate in so-called resource caravans, which implies that resources are linked with one another by means of a positive gain spiral (Rini et al., 1999). Indeed, in their empirical work, Dikkers et al. (2010) reported that for more proactive employees, job resources have a stronger impact on work engagement. In a similar vein, and following Hobfoll (2001, p. 339), we expect that employees with a proactive coping style are the ones that are better able to capitalize from their job resources, such as the learning value of one's job, and by doing so, shape their employability (see also Van der Heijden et al., 2015).

Otherwise stated, employees with a high amount of proactive coping will initiate a constructive path for further employability enhancement. They will manifest behaviors, such as long-term planning, expertise development and (practical, informational and emotional) resource accumulation (Greenglass, 1993), in order to make the most of their job and its value toward their learning and further development. When the individual employee takes responsibility for using opportunities for life-long learning, he/she transforms into an employability-enhancing worker (O’Donoghue and Maguire, 2005).

We argue that individuals who believe in their own competencies, and who have trust in their abilities to exert control, might be more likely to practice conscientiously and deliberately in their job (see also Macnamara et al., 2014). As a result of this deliberate practice and experience, they might take more advantage of the opportunities in their environment (Bateman and Crant, 1993), such as a job with a high learning value (Bateman and Crant, 1993). Based on the outline given above, we formulated the following moderation hypothesis:

H3. The relationship between learning value of the job and workers' employability is moderated by a proactive coping style. With a higher proactive coping style, the relationship is assumed to be more strongly positive.

\section{Method}

Sample and procedure

Data were collected using an online survey among academic staff employees working at the Open University of the Netherlands (OUNL). Like the British Open University, the OUNL is - just as the majority of the higher education institutions in the Netherlands - a teaching university that mainly adopts distance-learning technologies (e.g. virtual classrooms and other technology-supported individual and group learning activities) combined with some face-to-face learning activities. These learning activities are facilitated by academic staff who have a research assignment as well (which is common in the Netherlands). The OUNL is aimed at facilitating students who want to combine a Bachelor's or Master's program with their other work and family obligations. The final study sample consisted of 139 academic employees (41.4 percent response rate), all working as faculty staff members across different Science, Technology, Engineering and Mathematics and Social Sciences disciplines, with 53.2 percent of the respondents being male. All told, 43.2 percent of respondents had a part-time job, their average tenure was 9.61 years $(\mathrm{SD}=6.05)$, and their mean age was 46.36 years $(\mathrm{SD}=10.42$; age range $24-65$ years). Our response rate, around 40 percent, corresponds to those found in similar approaches (see Cook et al., 2000; Kerlinger, 1986). The data set contained no missing data.

\section{Measures}

Learning value of the job was measured with the thoroughly validated learning value of the job instrument, including six items. The items were "The experience I gain in my job encourages me to develop new capabilities" (i.e. acts as a nutrient for further learning), 
"My present job and my responsibilities require met to further develop my capabilities," "I can learn more and more from my job," "My job enables me to reach the limits of my capabilities," "My job enables me to further develop my talents" and "In my work I can completely utilize my capabilities."

Employees could respond to each of the statements using a six-point rating scale ranging from (1) strongly disagree to (6) strongly agree (Cronbach's $\alpha=0.86$ ). The measure's psychometric qualities are good, and the scale showed correlations to other variables as expected, thereby showing high levels of construct validity (see Van der Heijden and Bakker, 2011). Cross-cultural research in seven European countries showed that Cronbach's $\alpha$ ranged from 0.74 to 0.90 , depending upon country (Van der Heijden, Boon, Van der Klink and Meijs, 2009; Van der Heijden et al., 2010).

LMX was measured with Graen and Uhl-Bien's (1995) thoroughly validated seven-item scale, with all items scored on a five-point rating scale. An example item was, "How well does your leader understand your job problems and needs?" ranging from (1) not at all to (5) a great deal (Cronbach's $\alpha$ was 0.92). All items scored on a five-point rating scale.

Proactive coping style was measured with the scale developed by Greenglass $e t$ al. (1999). This reliable and valid scale comprised 14 items that were all scored on a four-point rating scale. An example item was, "When I experience a problem, I take the initiative in resolving it," ranging from (1) not at all true to (4) completely true (Cronbach's $\alpha$ was 0.80 ).

Employability was measured with Van der Heijde and Van der Heijden's (2006) multi-dimensional instrument, which consists of five scales and has proven to have sound psychometric qualities (see also Van der Heijden, De Lange, Demerouti and Van der Heijde, 2009): occupational expertise (15 items); anticipation and optimization (8 items); personal flexibility ( 8 items); corporate sense ( 7 items); and balance (9 items). Examples of items are "I consider myself competent to engage in in-depth, specialist discussions in my job domain" (occupational expertise), ranging from (1) not at all to (6) extremely (Cronbach's $\alpha=0.92$ ); "I take responsibility for maintaining my labor market value" (anticipation and optimization), ranging from (1) not at all to (6) to a considerable degree (Cronbach's $\alpha=0.82$ ); "I adapt to developments within my organization" (personal flexibility), ranging from (1) very poorly to (6) very well (Cronbach's $\alpha=0.79$ ); "I am involved in achieving my organization's/ department's mission" (corporate sense; Cronbach's $\alpha=0.81$ ); and "I suffer from workrelated stress" (balance), both ranging from (1) not at all to (6) to a considerable degree (Cronbach's $\alpha=0.81$ ). Empirical tests on its reliability and convergent, discriminant and predictive validity (for career success) have yielded sound outcomes (see also Van der Heijden and Bakker, 2011; Van der Heijden, De Lange, Demerouti and Van der Heijde, 2009; Veld, Van der Heijden, and Semeijn, 2016). Cross-cultural research in seven European countries showed that, depending upon country, Cronbach's $\alpha$ ranged from 0.82 to 0.96 for the occupational expertise measure, from 0.67 to 0.91 for anticipation and optimization, from 0.68 to 0.89 for personal flexibility, from 0.83 to 0.92 for corporate sense and from 0.82 to 0.96 for balance (Van der Heijden, Boon, Van der Klink and Meijs, 2009).

Given the outcomes of previous research (Ng et al., 2005; Van der Heijden et al., 2016), which showed that age might be related to the outcome (employability) and predictor (learning value of the job) of our study (Van der Heijden et al., 2016), we included age as a control variable (see also Ahmed et al., 2012; Froehlich et al., 2015; Van der Heijden, De Lange, Demerouti and Van der Heijde, 2009). Age was measured in year of birth and transformed to a variable that represents chronological age.

\section{Results}

Preliminary analyses

To test the factorial distinctiveness of the predictor, moderator and outcome variables, we conducted CFAs to compare the theoretically assumed measurement structure (i.e. eight latent
Moderating role of LMX and proactive coping 
CDI

24,2

170

first-order factors: five employability dimensions, learning value of the job, LMX and proactive coping style) with a one-factor model, wherein all items load on one latent first-order factor. If the eight-factor model reveals a better fit, the applied measures can be empirically separated in our sample and further applied for hypotheses testing. Moreover, favoring the eight-factor model above the one-factor model also points toward reduced common-method bias (Herman single-factor test; Podsakoff et al., 2003). The comparison of the eight-factor CFA model with the $\mathrm{g}$-factor model revealed that the eight-factor model fitted the data clearly better than the one-factorial model $\left(\Delta \chi^{2}(28)=1,743.23, p<0.001\right.$; eight-factor model: $\chi_{2}^{2}=3,794.60$, $\mathrm{df}=2,575, \chi^{2} / \mathrm{df}=1.47, \mathrm{RMSEA}=0.058, \mathrm{SRMR}=0.089$; one-factor model: $\chi^{2}=5,537.83$, $\mathrm{df}=2,603, \chi^{2} / \mathrm{df}=2.13$, RMSEA $=0.090, \mathrm{SRMR}=0.121$ ).

Table I shows the means, standard deviations and Pearson $r$ 's correlations as an initial overview of the empirical relations. Learning value of the job was small to moderately positively related to the moderation variables, and four of the five employability dimensions, with occupational expertise being the only exception. Overall, LMX was not so strongly related to employability compared to proactive coping style. Regarding the control variable, age was negatively related to anticipation and optimization, and to personal flexibility.

\section{Hypotheses testing}

Data were analyzed using moderated regression analyses with SPSS 23. Before running the regression models, the predictor variables were centered. In a first step, age was entered as a control variable. In a second step, the main effect of the predictor variable learning value of the job was entered. In a third step, the main effect of the moderation variable (i.e. LMX or proactive coping style) was entered. In a fourth step, the specific interaction effect (between learning value of the job and LMX or proactive coping style, respectively) was entered. The five single dimensions of employability were treated as separate outcomes. Altogether, we estimated ten regression models (one predictor $\times$ two interactions $\times$ five outcomes). Finally, we calculated simple slope tests and, in case of a significant interaction, plotted the interaction for a better understanding of the nature of the interaction (Cohen et al., 2014).

Main effects of learning value of the job. In Tables II and III, the results of the moderated regression analyses can be seen. The main effects of learning value of the job can be seen within the second step of the regression models (values are the same in Tables II and III). Learning value of the job was positively related to anticipation and optimization $(\beta=0.31$, $p<0.001)$, corporate sense $(\beta=0.41, p<0.001)$ and balance $(\beta=0.20, p<0.05)$. However, no significant relations were found for occupational expertise and for personal flexibility. Therefore, in sum, $H 1$ was partially supported with our data. Beyond age, learning value of the job explained between 4 and 17 percent of the outcome variables, which are the distinguished employability dimensions.

Table I.

Means, standard deviations and Pearson's correlations for the study variables

\begin{tabular}{lrrrrrrrrrr}
\hline Variable & $M$ & \multicolumn{1}{c}{ SD } & 1 & 2 & 3 & 4 & 5 & 6 & 7 & 8 \\
\hline 1. Age in years & 46.36 & 10.42 & & & & & & & \\
2. Learning value of the job & 4.38 & 0.91 & -0.16 & & & & & & \\
3. LMX & 3.31 & 0.86 & -0.08 & $0.41^{* *}$ & & & & & \\
4. Proactive coping style & 2.95 & 0.36 & -0.03 & $0.23^{* *}$ & -0.04 & & & & \\
5. Occupational expertise & 4.72 & 0.51 & 0.10 & 0.11 & 0.05 & $0.47^{* *}$ & & & & \\
6. Anticipation and & & & & & & & & & & \\
$\quad$ optimization & 3.67 & 0.71 & $-0.19^{*}$ & $0.33^{* *}$ & 0.12 & $0.44^{* *}$ & $0.34^{* *}$ & & & \\
7. Personal flexibility & 4.23 & 0.52 & $-0.20^{*}$ & $0.18^{*}$ & 0.13 & $0.44^{* *}$ & $0.46^{* *}$ & $0.56^{* *}$ & & \\
8. Corporate sense & 3.68 & 0.68 & 0.07 & $0.39^{* *}$ & $0.26^{* *}$ & $0.40^{* *}$ & $0.43^{* *}$ & $0.44^{* *}$ & $0.49^{* *}$ & \\
9. Balance & 4.10 & 0.55 & -0.00 & $0.20^{*}$ & 0.16 & $0.22^{* *}$ & $0.25^{* *}$ & $0.32^{* *}$ & $0.35^{* *}$ & $0.28^{* *}$
\end{tabular}

Notes: $n=139$. Significance tests are two-tailed. $* p<0.05 ; * * p<0.01$ 
Table II.

Moderated regression analyses for learning value and leadermember exchange as predictors for employability 
CDI

24,2

172

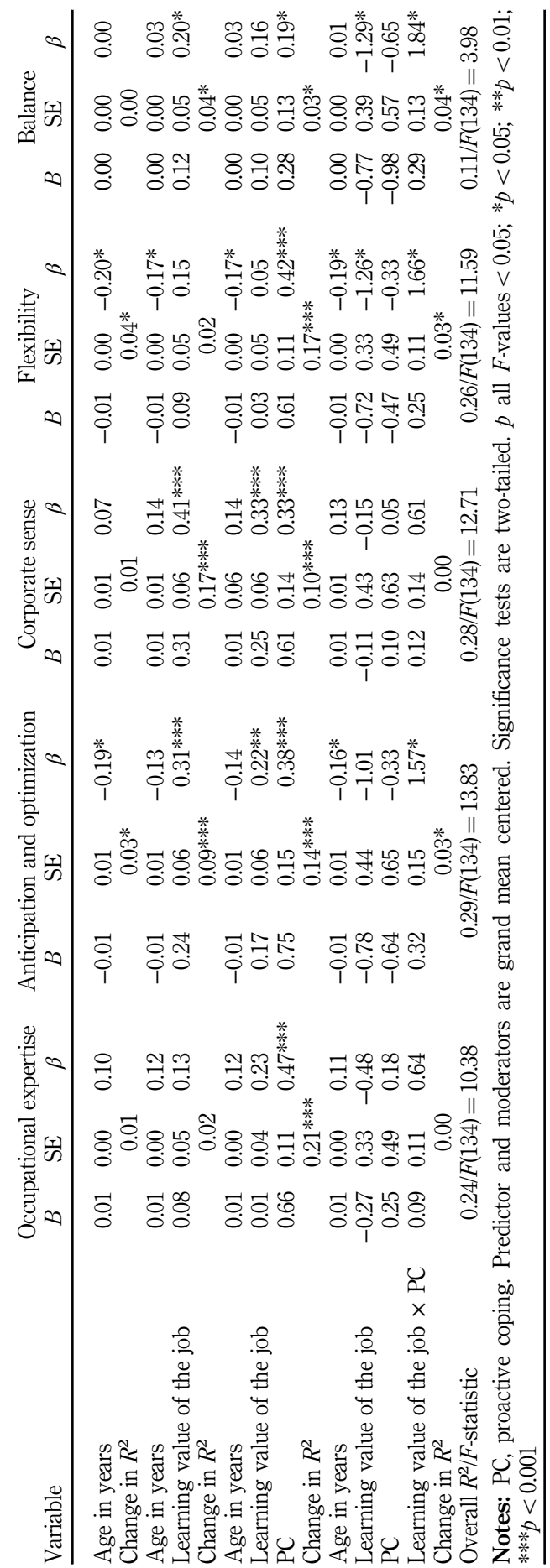

Table III.

Moderated regression analyses for learning value and proactive coping as predictors for employability 
Moderation effects of LMX. LMX did not show any additional direct effect beyond learning value of the job. However, as assumed by $H 2$, all interaction terms between learning value of the job and LMX appeared to have a significant impact on employability (see Table II). In more detail, the interaction term explained additional variance in all distinguished employability dimensions (for occupational expertise: $\beta=1.19, p<0.05$; for anticipation and optimization: $\beta=1.10, p<0.05$; for personal flexibility: $\beta=2.00, p<0.001$; for corporate sense: $\beta=1.71, p<0.01$; and for balance: $\beta=1.86, p<0.01$ ).

Simple slope tests showed that learning value of the job was positively related with all employability dimensions under conditions of high (+1 SD) LMX quality (for occupational expertise: $\beta=0.20, p<0.05$; for anticipation and optimization: $\beta=0.40, p<0.001$; for personal flexibility: $\beta=0.28, p<0.001$; for corporate sense: $\beta=0.50, p<0.001$; and for balance: $\beta=0.30, p<0.001$ ), yet not, or more weakly, related to employability under conditions of a low ( -1 SD) LMX quality (for anticipation and optimization: $\beta=0.16$, $p<0.05$; for all other dimensions, the $p$-values were above 0.05$)$. Figures $1-5$ show the specific interaction effects plotted for the five employability dimensions separately. The interaction effects explained between 3 and 9 percent of additional variance in the outcomes. Altogether, $H 2$ was fully supported with our data.

Moderation effects of proactive coping style. A proactive coping style showed additional main effects beyond learning value of the job for all employability dimensions (with all

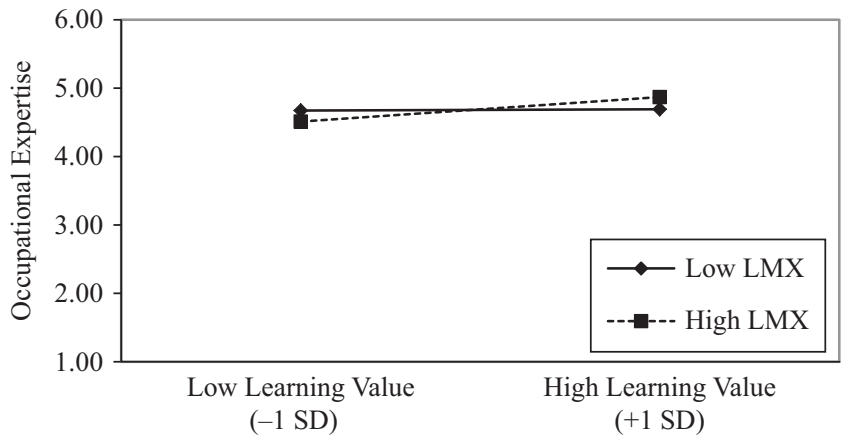

Notes: $\mathrm{Low} \mathrm{LMX}=-1 \mathrm{SD}$; high $\mathrm{LMX}=+1 \mathrm{SD}$

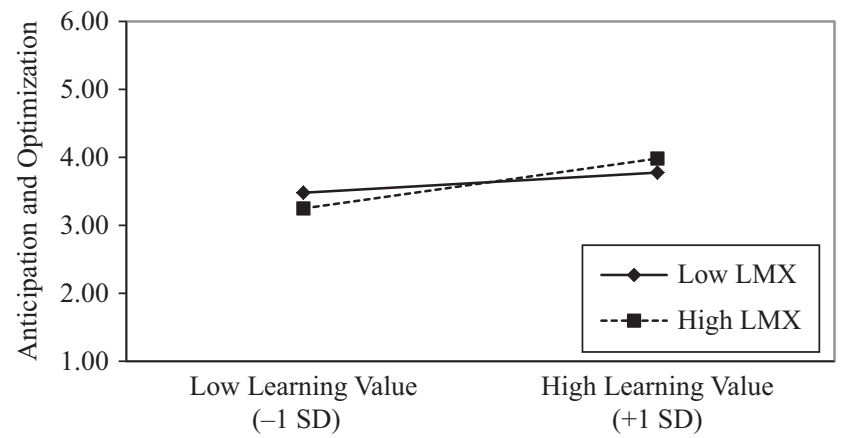

Notes: Low $\mathrm{LMX}=-1 \mathrm{SD}$; high $\mathrm{LMX}=+1 \mathrm{SD}$
Moderating role of LMX and proactive coping
Figure 1. LMX as a moderator for the learning value - occupational expertise relationship
Figure 2. LMX as a moderator for the learning value - anticipation and optimization relationship 
CDI

24,2

\section{4}

Figure 3.

LMX as a moderator

for the learning value - flexibility relationship

Figure 4.

LMX as a moderator for the learning value - corporate sense relationship

Figure 5.

LMX as a moderator for the learning value - balance relationship

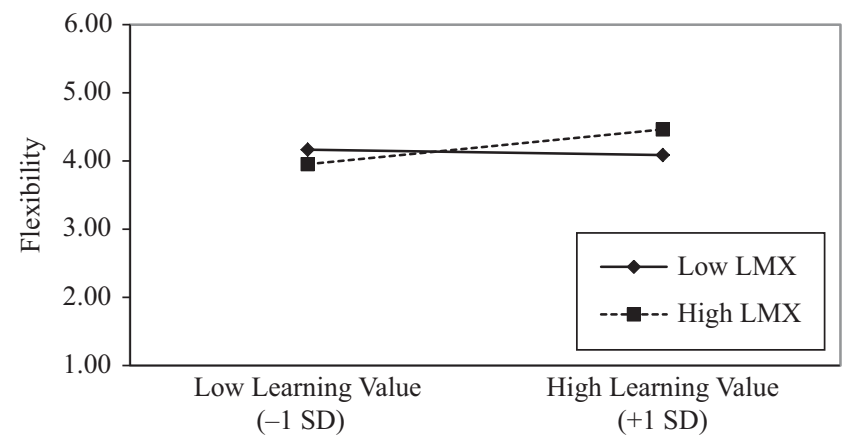

Notes: Low $\mathrm{LMX}=-1 \mathrm{SD}$; high $\mathrm{LMX}=+1 \mathrm{SD}$

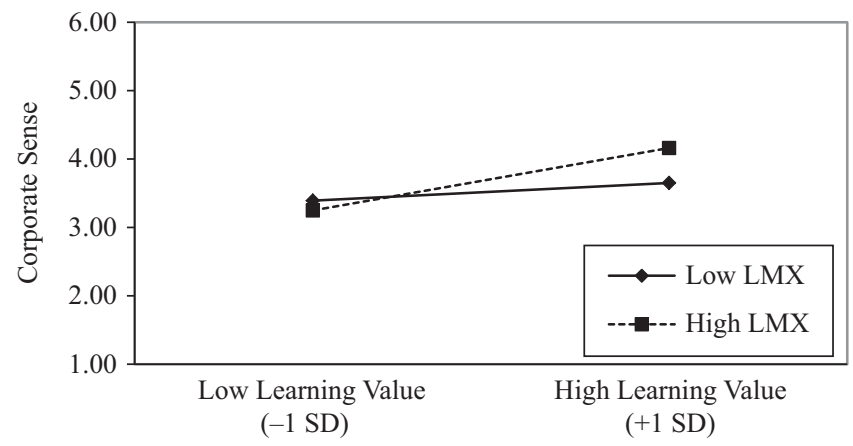

Notes: Low $\mathrm{LMX}=-1 \mathrm{SD}$; high $\mathrm{LMX}=+1 \mathrm{SD}$

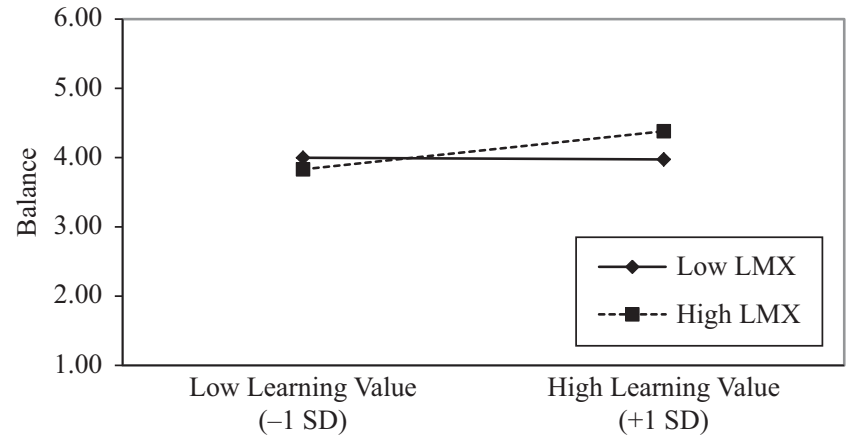

Notes: Low $\mathrm{LMX}=-1 \mathrm{SD}$; high $\mathrm{LMX}=+1 \mathrm{SD}$

$p$-values being below 0.001 , except when balance was the outcome variable, see Table III). Moreover, as assumed by $H 3$, some interaction terms between learning value of the job and proactive coping style appeared to have a significant impact on some employability dimensions (see Table III). In more detail, the interaction terms explained additional 
variance for anticipation and optimization $(\beta=1.57, p<0.05)$, personal flexibility $(\beta=1.66$, $p<0.05)$ and balance $(\beta=1.84, p<0.05)$. For occupational expertise and corporate sense, no interaction effects were detected, all $p$-values were above 0.05 .

Simple slope tests showed that learning value of the job was positively related with anticipation and optimization, personal flexibility and balance under conditions of a high $(+1 S D)$ proactive coping style (for anticipation and optimization: $\beta=0.28, p<0.001$; personal flexibility: $\beta=0.11, p<0.05$; balance: $\beta=0.19, p<0.01$ ), whereas the $p$-values for the other two employability dimensions were above 0.05 , yet not related to these three employability dimensions under conditions of a low $(-1 \mathrm{SD})$ proactive coping style (with all $p$-values being above 0.05 ). Figures $6-8$ show the interaction effects plotted for the significant interactions separately. The interaction effects appeared to explain between 3 and 4 percent of additional variance in the outcomes. In sum, $H 3$ was partially supported with our data.

\section{Post hoc analyses: testing three-way interactions}

For a more detailed understanding of the investigated effects, we also tested the possibility of three-way interactions for every employability dimension. Therefore, we estimated regression models where the three-way interaction (learning value of the job $\times$ LMX $\times$ proactive coping) was included in a final regression step. The results revealed that only for

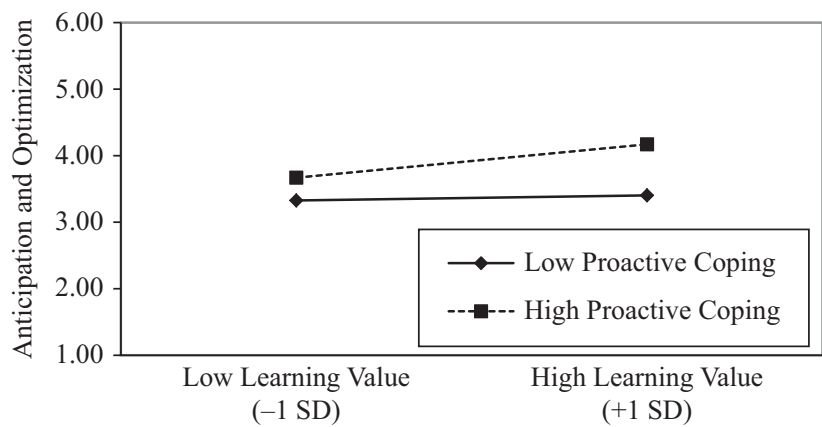

Notes: Low proactive coping $=-1 \mathrm{SD}$; high proactive coping $=+1 \mathrm{SD}$

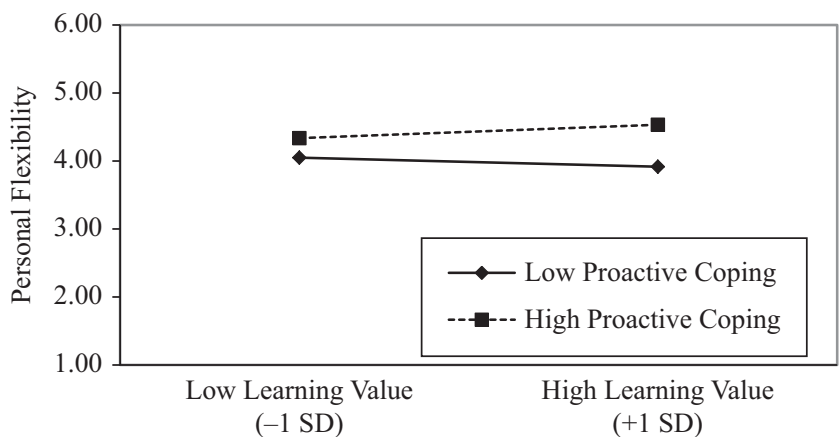

Notes: Low proactive coping $=-1 \mathrm{SD}$; high proactive coping $=+1 \mathrm{SD}$
Moderating role of LMX and proactive coping
Figure 6. Proactive coping style as a moderator for the learning value - anticipation and optimization relationship
Figure 7. Proactive coping style as a moderator for the learning value personal flexibility relationship 
CDI

24,2

anticipation and optimization the three-way interaction was marginally significant ( $\beta=0.17, p=0.054$, with an additionally explained variance of 2 percent), and with the strongest effect of learning value of the job on anticipation and optimization under conditions of high (+1 SD) LMX and proactive coping (simple slope test: $\beta=0.44, p<0.001$ ). The three-way interaction is graphically depicted in Figure 9.

\section{6}

\section{Discussion}

\section{Reflection on the outcomes}

This study analyzed under which conditions (i.e. LMX quality and proactive coping style) the learning value of the job is particularly related to the worker's employability enhancement of Dutch university staff. As such, an interactionist perspective (Endler and Magnusson, 1976; Lewin, 1935) was adopted by incorporating learning value of the job as

Figure 8.

Proactive coping style as a moderator for the learning value - balance relationship
Figure 9.

Three-way interaction: LMX and proactive coping style as joint moderators for the learning value anticipation and optimization relationship

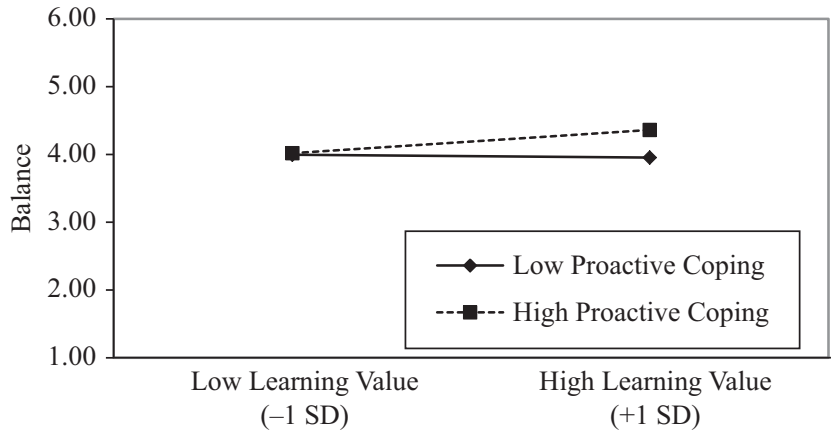

Notes: Low proactive coping $=-1 \mathrm{SD}$; high proactive coping $=+1 \mathrm{SD}$

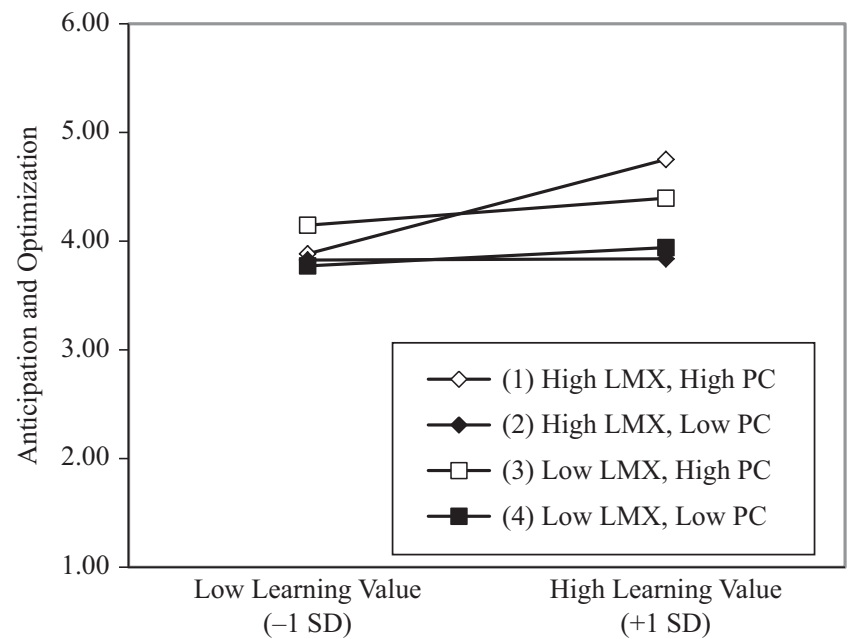

Notes: LMX, leader-member exchange; PC, proactive coping style. Low $\mathrm{PC} / \mathrm{LMX}=-1 \mathrm{SD}$; high $\mathrm{PC} / \mathrm{LMX}=+1 \mathrm{SD}$ 
the predictor, and two moderators: one contextual variable (i.e. LMX), and one personal one (i.e. employee proactive coping style).

Results partially supported our hypotheses because learning value of the job was related to some employability dimensions, and this relationship was indeed strengthened by a higher LMX quality and a higher proactive coping style. However, for some employability dimensions, learning value of the job was not a direct predictor (i.e. occupational expertise and personal flexibility), and for some dimensions, proactive coping was not a moderator (i.e. occupational expertise and corporate sense). Both the expected findings as well the unexpected ones provide further insight for career development and related employability models.

The finding that the learning value of the job was related differently to the unique employability dimensions underscores that learning characteristics of the job have their impact on the employee's career development through some unique employability dimensions (see also Van der Heijden et al., 2016). The fact that learning value of the job did not predict occupational expertise and personal flexibility indicates that, apparently, learning value of the job is especially beneficial for an individual's broader development, rather than for growth in his/her current expertise area. A possible explanation for this somewhat counterintuitive finding might be that perceptions of occupational expertise are more based on formal learning programs than on indirect learning via valuable resources (such as job characteristics) in one's environment.

Regarding the moderating effects, we have found some very promising results as well. More specifically, when LMX was the moderator, full support (i.e. for all five employability dimensions) was found, whereas when proactive coping style was the moderator, partial support (i.e. for three out of five employability dimensions: anticipation and optimization, personal flexibility and balance) was found. Expressed differently, LMX strengthens the relationships between learning value of the job and employability dimensions, where no significant relationship was visible without considering this moderator. The same pattern was the case for proactive coping style as the moderator, and the employability dimension of personal flexibility. This highlights the importance of studying personal and contextual reinforcing processes to boost individual career development (see also Demerouti and Bakker, 2011).

One explanation for why proactive coping style was not a consistent moderator as was LMX might be that proactive coping style was more strongly related to learning value of the job compared to LMX. Hence, it might also be the case that proactive individuals generate more work situations with a higher learning value that then still needs to be supported by a high LMX relationship. On a methodological level, this means that the relatively strong main effects of proactive coping style, compared to the main effects of LMX, might have partialled out important variance for detecting the interaction effects (Cohen et al., 2014).

In sum, the results of this study add to the relatively scarce literature in LMX-related moderation models (Martin et al., 2016), and to the literature on proactivity (Frese et al., 2007), by investigating a model combining workplace characteristics and individual proactivity. Our findings are in line with the theoretical approaches as formulated in the JDR framework (Bakker and Demerouti, 2007; Demerouti et al., 2001) and Hobfoll's $(1988,1989)$ COR theory, and revealed that employees who take responsibility for using possible resources at work transform into employability-enhancing workers (Demerouti and Bakker, 2011; O’Donoghue and Maguire, 2005).

\section{Practical implications}

As academic staff comprises an under-researched professional category (Baruch et al., 2014), which is confronted with an increase in job insecurity, a better understanding of the
Moderating role of LMX and proactive coping 
CDI

24,2

predictive value of career-related continuous learning is of utmost importance (Rowold and Schilling, 2006). Moreover, nowadays, job qualifications are changing and becoming more complex at an ever-increasing rate, and it is very useful to have found empirical evidence for the fact that the learning value of the job is especially beneficial for an individual's broader development, rather than for growth in his/her current expertise area.

This study provides empirically validated suggestions for an individual's career development, as well as for constructive career counseling and HRM practices. First, our study suggests that informal learning potential at the workplace itself might be an important way of shaping one's employability. Therefore, one recommendation for individuals might be to search for jobs that provide this learning value, or to actively craft their jobs to provide more challenges. Job crafting research has shown that individuals indeed have the possibility to increase their challenges at work, which is somewhat related to new learning opportunities (Petrou et al., 2012).

Second, our results also suggest that by actively training for a proactive coping style, individuals might benefit most from their work environment in terms of employability enhancement across the life span (for instance, see Ouwehand et al., 2007). Next to portraying a proactive coping style, we see opportunities for further shaping or optimizing the psychological contract between the employee and his/her direct supervisor (Rousseau, 2001). In case the employee is willing to go the extra mile (see LePine et al., 2002 for a discussion on Organizational Citizenship Behavior), it is likely that the supervisor will respond with a high-quality management style. Given the outcomes of the tested moderation effects, it is encouraging to know that both supervisor and employee can - with interaction that is characterized by both high-quality supervision (LMX) and a proactive attitude (coping style) - contribute to the necessary employability enhancement in contemporary careers (see also De Vos and Van der Heijden, 2015).

Third, organizations might apply HRM strategies and practices that refer to the learning value of the job or LMX, and thereby indirectly affect the worker's employability. It might be helpful to consult a career specialist to critically reflect on the learning value of one's job, as well as to increase other career development enhancing practices in the employee's current assignment (Van der Heijden and Bakker, 2011). In addition, leadership programs that are related to transformational leadership styles (Barling et al., 1996) might enhance the LMX quality of employees with their supervisors, and therefore also indirectly affect an individual's employability. In sum, the results of our study suggest that both the employee him- or herself and his/her occupational environment (e.g. career counseling or HRM strategies and practices) have different possibilities to enhance employability within the workforce.

\section{Limitations of the study}

The present study also has some limitations. First, as all data have been collected using survey research, some response set consistencies or common-method bias may exist (Podsakoff et al., 2012). Therefore, we did our best to minimize common-method variance when designing the study, for example, by applying short questionnaires and a mix of different response formats and labeling, as recommended in procedural methods for reducing common-method bias (Podsakoff et al., 2012). However, due to the restricted sample size, we were unable to apply complex statistical methods to control for commonmethod bias. Nonetheless, the simpler Herman's single-factor test showed that the applied measures were clearly separated from each other (see Results' section), indicating that common-method bias was slightly reduced (Podsakoff et al., 2003).

Second, given our focus on one occupational sector (i.e. academic faculty staff) and from one country (the Netherlands), further research is needed to address issues of generalizability to other occupational settings and/or to other countries. As university staff works under 
different labor conditions than, for instance, employees from the private industry or the selfemployed, more research across different occupational sectors is needed. Specifically, tests of whether the results are occupationally, or culturally, invariant would be needed.

Third, on the one hand, as only self-ratings have been used in this study, more scholarly work is needed to better understand how this might have influenced our pattern of results. On the other hand, regarding our outcome measure, past research has shown that other-ratings of employability are less differentiated and show less variance between the employability sub-dimensions (Van der Heijden et al., 2016). Against this background, self-ratings of employability seem to have been an appropriate choice for gaining a more nuanced picture in this particular study. Nonetheless, multi-source data would be interesting to have, to better understand whether the individual employee and his/her supervisor differ regarding their perceptions of the quality of the employee's job in light of further professional development, on the quality of their relationship and on the employee's amount of proactivity in light of employability enhancement.

\section{Recommendations for future research}

This study was cross-sectional. Conducting multi-wave designs would shed more light on the stability and change of the variables in our research model, and on cross-lagged (i.e. over time) relationships compared with our cross-sectional approach (Spurk and Abele, 2014). Related to this, reciprocal relationships (e.g. cross-lagged effects between antecedents and outcomes) might be taken into account. For example, it might be that more employable individuals are also more actively searching for, and drifting into, jobs that provide a stronger learning value or environment. As a result, they might even become more employable, which would result in positive reciprocal relations between the study variables.

As mentioned earlier in this study, employability enhancement might best be described as a multi-facetted endeavor, which should consider personal and contextual factors. We have provided an in-depth investigation about how and when the learning value of the job contributes to workers' employability. However, future research might expand this line of research by adding further mediators or moderators. Specifically, it might be interesting to investigate the role of different demands (e.g. time pressure, workload) as moderators of the learning value of the job-employability linkage, or to expand the moderators to other resources or demands outside work, or at the boundaries of the work and non-work domains.

Finally, it is important to identify a broader network of variables, specifically within the work and non-work environment of the employee, which directly affect the employability of the worker. Such a strategy would allow one to derive even broader implications for HR practices and sustainable individual career development.

\section{Conclusion}

Knowledge about environmental factors that contribute to an individual's employability enhancement is of theoretical and practical relevance, yet is, however, still rare. The results of this study add important knowledge about how environmental factors (learning value of the job and LMX) and individual factors (proactive coping style) may be applied within individual and organizational career development. A combination of a job with a high learning value on the one hand, and high LMX and proactive coping style on the other hand, seems especially fruitful for enhancing an employee's employability. Hence, the question "Who's in charge when it comes to employability?" is best answered by "both" (i.e. the individual in combination with his/her work-related context, represented by means of important stakeholders, such as one's direct supervisor; see also (De Vos et al., 2018; Van der Heijden and De Vos, 2015), as the latter has an important influence on the characteristics of the job as well as on resources to facilitate the employee to make the best of his/her current job.
Moderating role of LMX and proactive coping 
CDI

24,2

\section{References}

Ahmed, A.M., Andersson, L. and Hammarstedt, M. (2012), "Does age matter for employability? A field experiment on ageism in the Swedish labour market", Applied Economics Letters, Vol. 19 No. 4, pp. 403-406.

Amabile, T.M., Conti, R., Coon, H., Lazenby, J. and Herron, M. (1996), "Assessing the work environment for creativity”, Academy of Management Journal, Vol. 39 No. 5, pp. 1154-1184.

Bakker, A.B. (2011), "An evidence-based model of work engagement", Current Directions in Psychological Science, Vol. 20 No. 4, pp. 265-269.

Bakker, A.B. and Demerouti, E. (2007), "The job demands-resources model: state of the art”, Journal of Managerial Psychology, Vol. 22 No. 3, pp. 309-328.

Bakker, A.B., Tims, M. and Derks, D. (2012), "Proactive personality and job performance: the role of job crafting and work engagement”, Human Relations, Vol. 65 No. 10, pp. 1359-1378.

Bandura, A. (1992), "Exercise of personal agency through the self-efficacy mechanism", in Schwarzer, R. (Ed.), Self-efficacy: Thought Control of Action, Hemisphere, Washington, DC, pp. 3-38.

Barling, J., Weber, T. and Kelloway, E.K. (1996), "Effects of transformational leadership training on attitudinal and financial outcomes: a field experiment", Journal of Applied Psychology, Vol. 81 No. 6, pp. 827-832.

Baruch, Y. and Hall, D.T. (2004), "The academic career: a model for future careers in other sectors?", Journal of Vocational Behavior, Vol. 64 No. 2, pp. 241-262.

Baruch, Y., Dany, F., Pralong, J. and Davense, C. (2014), "Managing academic careers: global perspectives", Career Development International, Vol. 19 No. 3, available at: https://doi.org/10.110 8/CDI-03-2014-0045

Bateman, T.S. and Crant, J.M. (1993), “The proactive component of organizational behavior: a measure and correlates", Journal of Organizational Behavior, Vol. 14 No. 2, pp. 103-118.

Berings, M.G.M.C., Poell, R.F. and Simons, P.J. (2008), "Dimensions of on-the-job learning styles", Applied Psychology: An International Review, Vol. 57 No. 3, pp. 417-440.

Berntson, E., Sverke, M. and Marklund, S. (2006), "Predicting perceived employability: human capital or labour market opportunities?”, Economic and Industrial Democracy, Vol. 27 No. 2, pp. 223-244.

Blau, P. (1964), Exchange and Power in Social Life, John Wiley, New York, NY.

Boerlijst, J.G., Van der Heijden, B.I.J.M. and Van Assen, A. (1993), Veertigplussers in de onderneming (Over-Forties in the Organization), Uitgeverij Van Gorcum.

Brown, P., Green, A. and Lauder, H. (2001), High Skills: Globalisation, Competitiveness and Skill Formation, Oxford University Press, Oxford.

Cappelli, P. and Sherer, P.D. (1991), "The missing role of context in OB: the need for a meso-level approach", in Cummings, L.L. and Staw, B.M. (Eds), Research in Organizational Behavior, Vol. 13, JAI Press, Greenwich, CT, pp. 55-110.

Cheetham, G. and Chivers, G. (2001), "How professionals learn in practice: an investigation of informal learning amongst people working in professions", Journal of European Industrial Training, Vol. 25 No. 5, pp. 247-292.

Clarke, M. and Patrickson, M. (2008), “The new covenant of employability”, Employee Relations, Vol. 30 No. 2, pp. 121-141.

Cohen, J., Cohen, P., West, S.G. and Aiken, L.S. (2014), Applied Multiple Regression/Correlation Analysis for the Behavioral Sciences, Psychology Press, New York, NY.

Cook, C., Heath, F. and Thompson, R.L. (2000), "A meta-analysis of response rates in web- or internet-based surveys", Educational and Psychological Measurement, Vol. 60 No. 6, pp. 821-836.

Cropanzano, R. and Mitchell, M.S. (2005), “Social exchange theory: an interdisciplinary review”, Journal of Management, Vol. 31 No. 6, pp. 874-900. 
De Pater, I.E., Van Vianen, A.E., Fischer, A.H. and Van Ginkel, W.P. (2009), "Challenging experiences: gender differences in task choice", Journal of Managerial Psychology, Vol. 24 No. 1, pp. 4-28.

De Vos, A. and Van der Heijden, B.I.J.M. (2015), Handbook of Research on Sustainable Careers, Edward Elgar Publishing Limited, Cheltenham and Northampton, MA.

De Vos, A., De Hauw, S. and Van der Heijden, B.I.J.M. (2011), "Competency development and career success: the mediating role of employability", Journal of Vocational Behavior, Vol. 79 No. 2, pp. 438-447.

De Vos, A., Van der Heijden, B.I.J.M. and Akkermans, J. (2018), "Sustainable careers: towards a conceptual model", Journal of Vocational Behavior.

De Weert, E. (2001), "Pressures and prospects facing the academic profession in the Netherlands", Higher Education, Vol. 41 Nos 1/2, pp. 77-101.

Demerouti, E. and Bakker, A.B. (2011), "The job demands-resources model: challenges for future research", SA Journal of Industrial Psychology, Vol. 37 No. 2, pp. 1-9.

Demerouti, E., Bakker, A.B., Nachreiner, F. and Schaufeli, W.B. (2001), "The job demands-resources model of burnout", Journal of Applied Psychology, Vol. 86 No. 3, pp. 499-512.

Den Hartog, D.N. and Belschak, F.D. (2007), "Personal initiative, commitment and affect at work", Journal of Occupational and Organizational Psychology, Vol. 80 No. 4, pp. 601-622.

DeRue, D.S. and Wellman, N. (2009), "Developing leaders via experience: the role of developmental challenge, learning orientation, and feedback availability", Journal of Applied Psychology, Vol. 94 No. 4, pp. 859-875.

Dikkers, J.S., Jansen, P.G., De Lange, A.H., Vinkenburg, C.J. and Kooij, D. (2010), "Proactivity, job characteristics, and engagement: a longitudinal study", Career Development International, Vol. 15 No. 1, pp. 59-77.

Dragoni, L., Tesluk, P.E., Russell, J.E.A. and Oh, I.S. (2009), “Understanding managerial development: integrating developmental assignments, learning orientation, and access to developmental opportunities in predicting managerial competencies", Academy of Management Journal, Vol. 52 No. 4, pp. 731-743.

Dulebohn, J.H., Bommer, W.H., Liden, R.C., Brouer, R.L. and Ferris, G.R. (2012), “A meta-analysis of antecedents and consequences of leader-member exchange: integrating the past with an eye toward the future", Journal of Management, Vol. 38 No. 6, pp. 1715-1759.

Endler, N.S. and Magnusson, D. (1976), "Toward an interactional psychology of personality", Psychological Bulletin, Vol. 83 No. 5, pp. 956-974.

Eraut, M. (2004), "Informal learning in the workplace", Studies in Continuing Education, Vol. 26 No. 2, pp. 247-273.

Erdogan, B. and Bauer, T.N. (2005), "Enhancing career benefits of employee proactive personality: the role of fit with jobs and organizations", Personnel Psychology, Vol. 58 No. 4, pp. 859-891.

Evers, A.T., Kreijns, K., Van der Heijden, B.I.J.M. and Gerrichhauzen, J.T.G. (2011), “An organizational and task perspective model aimed at enhancing teachers' professional development and occupational expertise”, Human Resource Development Review, Vol. 10 No. 2, pp. 151-179.

Forrier, A., Verbruggen, M. and De Cuyper, N. (2015), "Integrating different notions of employability in a dynamic chain: the relationship between job transitions, movement capital and perceived employability", Journal of Vocational Behavior, Vol. 89, pp. 56-64.

Frese, M., Garst, H. and Fay, D. (2007), "Making things happen: reciprocal relationships between work characteristics and personal initiative in a four-wave longitudinal structural equation model", Journal of Applied Psychology, Vol. 92 No. 4, pp. 1084-1102.

Froehlich, D.E., Beausaert, S.A. and Segers, M.S. (2015), "Age, employability and the role of learning activities and their motivational antecedents: a conceptual model", The International Journal of Human Resource Management, Vol. 26 No. 16, pp. 2087-2101.

Fugate, M., Kinicki, A.J. and Ashforth, B.E. (2004), "Employability: a psycho-social construct, its dimensions, and applications", Journal of Vocational Behavior, Vol. 65 No. 1, pp. 14-38.
Moderating role of LMX and proactive coping 
CDI

24,2

Fuller, B. and Marler, L.E. (2009), "Change driven by nature: a meta-analytic review of the proactive personality literature", Journal of Vocational Behavior, Vol. 75 No. 3, pp. 329-345.

Gerstner, C.R. and Day, D.V. (1997), "Meta-analytic review of leader-member exchange theory: correlates and construct issues", Journal of Applied Psychology, Vol. 82 No. 6, pp. 827-844.

Gholifar, E., Hedjazi, S.Y., Hoseini, S.M. and Rezaei, A. (2011), "Human resource development: faculty members' psychological empowerment in Iran's colleges", African Journal of Business Management, Vol. 5 No. 31, pp. 12249-12255.

Gooty, J. and Yammarino, F.J. (2016), “The leader-member exchange relationship: a multisource, crosslevel investigation", Journal of Management, Vol. 42 No. 4, pp. 915-935.

Gosling, D. (2009), "Educational development in the UK: a complex and contradictory reality", International Journal for Academic Development, Vol. 14 No. 1, pp. 5-18.

Graen, G.B. and Uhl-Bien, M. (1995), "Relationship-based approach to leadership: development of leader-member exchange (LMX) theory of leadership over 25 years: applying a multi-level multi-domain perspective", The Leadership Quarterly, Vol. 6 No. 2, pp. 219-247.

Greenglass, E.R. (1993), "The contribution of social support to coping strategies", Applied Psychology: An International Review, Vol. 42 No. 4, pp. 323-340.

Greenglass, E.R. (2002), "Proactive coping and quality of life management", in Frydenberg, E. (Ed.), Beyond Coping: Meeting Goals, Visions, and Challenges, Oxford University Press, New York, NY, pp. 37-62.

Greenglass, E.R., Schwarzer, R., Jakubiec, D., Fiksenbaum, L. and Taubert, S. (1999), "The proactive coping inventory (PCI): a multidimensional research instrument", paper presented at the 20th International Conference of the Stress and Anxiety Research Society, July 12-14, Cracow.

Griffin, G., Green, T. and Medhurst, P. (2005), "The relationship between the process of professionalization in academe and interdisciplinarity: a comparative study of eight European countries", University of Hull, available at: https://york.ac.uk/res/researchintegration/ ComparativeReports/Comparative_Report_Profesionalization_and_Interdisciplinarity.pdf

Groot, W. and Maassen van den Brink, H. (2000), "Overeducation in the labor market: a meta-analysis”, Economics of Education Review, Vol. 19 No. 2, pp. 149-158.

Harris, K.J., Wheeler, A.R. and Kacmar, K.M. (2011), "The mediating role of organizational job embeddedness in the LMX - outcomes relationships", The Leadership Quarterly, Vol. 22 No. 2, pp. 271-281.

Hobfoll, S.E. (1988), The Ecology of Stress, Taylor \& Francis.

Hobfoll, S.E. (1989), "Conservation of resources: a new attempt at conceptualizing stress", The American Psychologist, Vol. 44 No. 3, pp. 513-524.

Hobfoll, S.E. (2001), "The influence of culture, community, and the nested-self in the stress process: advancing conservation of resources theory", Applied Psychology: An International Review, Vol. 50 No. 3, pp. 337-421.

Holman, D., Epitropaki, O. and Fernie, S. (2001), "Understanding learning strategies in the workplace: a factor analytic investigation", Journal of Occupational and Organizational Psychology, Vol. 74 No. 5, pp. 675-681.

Hornung, S., Rousseau, D.M., Glaser, J., Angerer, P. and Weigl, M. (2010), "Beyond top-down and bottom-up work redesign: customizing job content through idiosyncratic deals", Journal of Organizational Behavior, Vol. 31 Nos 2-3, pp. 187-215.

Jacobs, R. and Jones, M. (1995), Structured on-the-Job Training: Developing Expertise in the Workplace, Berrett-Koehler, San Francisco, CA.

Kamdar, D. and Van Dyne, L. (2007), "The joint effects of personality and workplace social exchange relationships in predicting task performance and citizenship performance", Journal of Applied Psychology, Vol. 92 No. 5, pp. 1286-1298.

Keller, T. and Dansereau, F. (1995), "Leadership and empowerment: a social exchange perspective", Human Relations, Vol. 48 No. 2, pp. 127-146. 
Kerlinger, F.N. (1986), Foundations of Behavioral Research, 3rd ed., Holt, Rinehart \& Winston, New York, NY.

King, Z. (2004), "Career self-management: its nature, causes and consequences", Journal of Vocational Behavior, Vol. 65 No. 1, pp. 112-133.

Kohn, M.L. and Schooler, C. (1982), "Job conditions and personality: a longitudinal assessment of their reciprocal effects", American Journal of Sociology, Vol. 87 No. 6, pp. 1257-1283.

Kuijpers, M.A.C.T. and Scheerens, J. (2006), “Career competencies for the modern career”, Journal of Career Development, Vol. 32 No. 4, pp. 303-319.

Kuvaas, B. and Dysvik, A. (2009), "Perceived investment in employee development, intrinsic motivation and work performance”, Human Resource Management Journal, Vol. 19 No. 3, pp. 217-236.

Kuvaas, B. and Dysvik, A. (2010), "Exploring alternative relationships between perceived investment in employee development, perceived supervisor support and employee outcomes", Human Resource Management Journal, Vol. 20 No. 2, pp. 138-156.

LePine, J.A., Erez, A. and Johnson, D.E. (2002), "The nature and dimensionality of organizational citizenship behavior: a critical review and meta-analysis", Journal of Applied Psychology, Vol. 87 No. 1, pp. 52-65.

Lewin, K. (1935), A Dynamic Theory of Personality - Selected Papers, McGraw, New York, NY.

Macnamara, B.N., Hambrick, D.Z. and Oswald, F.L. (2014), "Deliberate practice and performance in music, games, sports, education, and professions: a meta-analysis", Psychological Science, Vol. 25 No. 8, pp. 1608-1618.

Martin, R., Guillaume, Y., Thomas, G., Lee, A. and Epitropaki, O. (2016), "Leader-member exchange (LMX) and performance: a meta-analytic review”, Personnel Psychology, Vol. 69 No. 1, pp. 67-121.

Maurer, T.J., Weiss, E.M. and Barbeite, F.G. (2003), "A model of involvement in work-related learning and development activity: the effects of individual, situational, motivational, and age variables", Journal of Applied Psychology, Vol. 88 No. 4, pp. 707-724.

Mowday, R.T. and Sutton, R.I. (1993), "Organizational behavior: linking individuals and groups to organizational contexts", Annual Review of Psychology, Vol. 44 No. 1, pp. 195-229.

Nauta, A., Van Vianen, A., Van der Heijden, B.I.J.M., Van Dam, K. and Willemsen, M. (2009), "Understanding the factors that promote employability orientation: the impact of employability culture, career satisfaction, and role breadth self-efficacy", Journal of Occupational and Organizational Psychology, Vol. 82 No. 2, pp. 233-251.

Nazar, G. and Van der Heijden, B.I.J.M. (2014), "Possible selves and identity in relation to career development: evidence from Chilean male middle-aged managers' career narratives", International Journal of Training and Development, Vol. 18 No. 1, pp. 66-77.

Ng, T.W.H., Eby, L.T., Sorensen, K.L. and Feldman, D.C. (2005), "Predictors of objective and subjective career success: a meta-analysis", Personnel Psychology, Vol. 58 No. 2, pp. 367-408.

Nielsen, K., Randall, R., Yarker, J. and Brenner, S.O. (2008), "The effects of transformational leadership on followers' perceived work characteristics and psychological well-being: a longitudinal study", Work \& Stress, Vol. 22 No. 1, pp. 16-32.

O’Donoghue, J. and Maguire, T. (2005), "The individual learner, employability and the workplace: a reappraisal of relationships and prophecies", Journal of European Industrial Training, Vol. 29 No. 6, pp. 436-446.

Ouwehand, C., De Ridder, D.T. and Bensing, J.M. (2007), "A review of successful aging models: proposing proactive coping as an important additional strategy", Clinical Psychology Review, Vol. 27 No. 8, pp. 873-884.

Parker, S.K., Bindl, U.K. and Strauss, K. (2010), "Making things happen: a model of proactive motivation", Journal of Management, Vol. 36 No. 4, pp. 827-856.

Petrou, P., Demerouti, E., Peeters, M.C., Schaufeli, W.B. and Hetland, J. (2012), "Crafting a job on a daily basis: contextual correlates and the link to work engagement", Journal of Organizational Behavior, Vol. 33 No. 8, pp. 1120-1141. 
CDI

24,2

184

Podsakoff, P.M., MacKenzie, S.B. and Podsakoff, N.P. (2012), "Sources of method bias in social science research and recommendations on how to control it", Annual Review of Psychology, Vol. 63, pp. 539-569.

Podsakoff, P.M., MacKenzie, S.B., Lee, J.Y. and Podsakoff, N.P. (2003), "Common method biases in behavioral research: a critical review of the literature and recommended remedies", Journal of Applied Psychology, Vol. 88 No. 5, pp. 879-903.

Pulakos, E.D., Arad, S., Donovan, M.A. and Plamondon, K.E. (2000), "Adaptability in the workplace: development of a taxonomy of adaptive performance", Journal of Applied Psychology, Vol. 85 No. 4, pp. 612-624.

Raghuram, S., Gajendran, R.S., Liu, X. and Somaya, D. (2017), “Boundaryless LMX: examining LMX's impact on external career outcomes and alumni goodwill", Personnel Psychology, Vol. 70 No. 2, pp. 399-428.

Rini, C.K., Dunkel-Schetter, C., Wadhwa, P.D. and Sandman, C.A. (1999), "Psychological adaptation and birth outcomes: the role of personal resources, stress, and sociocultural context in pregnancy", Health Psychology, Vol. 18 No. 4, pp. 333-345.

Rousseau, D.M. (2001), "Schema, promise and mutuality: the building blocks of the psychological contract”, Journal of Occupational and Organizational Psychology, Vol. 74 No. 4, pp. 511-541.

Rowold, J. and Schilling, J. (2006), "Career-related continuous learning: longitudinal predictive power of employees' job and career attitudes", Career Development International, Vol. 11 No. 6 , pp. 489-503.

Sanders, J. and De Grip, A. (2004), "Training, task flexibility and the employability of low-skilled workers", International Journal of Manpower, Vol. 25 No. 1, pp. 73-89.

Schuster, J.H. and Finkelstein, M.J. (2006), The American Faculty: The Restructuring of Academic Work and Careers, JHU Press.

Schwarzer, R. and Taubert, S. (2002), "Tenacious goal pursuits and striving toward personal growth: proactive coping", in Frydenberg, E. (Ed.), Beyond Coping: Meeting Goals, Visions and Challenges, Oxford University Press, London, pp. 19-35.

Siivonen, P. and Isopahkala-Bouret, U. (2016), “Adult graduates' negotiations of age(ing) and employability”, Journal of Education and Work, Vol. 29 No. 3, pp. 352-372.

Spurk, D. and Abele, A.E. (2014), "Synchronous and time-lagged effects between occupational self-efficacy and objective and subjective career success: findings from a four-wave and 9-year longitudinal study", Journal of Vocational Behavior, Vol. 84 No. 2, pp. 119-132.

Spurk, D., Hirschi, A. and Dries, N. (2019), "Antecedents and outcomes of objective versus subjective career success: competing perspectives and future directions", Journal of Management, Vol. 45 No. 1 , pp. 35-69.

Sturges, J., Conway, N. and Liefooghe, A. (2010), "Organizational support, individual attributes, and the practice of career self-management behavior”, Group \& Organization Management, Vol. 35 No. 1, pp. 108-141.

Sullivan, S.E. and Baruch, Y. (2009), "Advances in career theory and research: a critical review and agenda for future exploration”, Journal of Management, Vol. 35 No. 6, pp. 1542-1571.

Thijssen, J.G.L., Van der Heijden, B.I.J.M. and Rocco, T.S. (2008), “Toward the employability-link model: current employment transition to future employment perspectives", Human Resource Development Review, Vol. 7 No. 2, pp. 165-183.

Thomas, J.P., Whitman, D.S. and Viswesvaran, C. (2010), "Employee proactivity in organizations: a comparative meta-analysis of emergent proactive construct", Journal of Occupational and Organizational Psychology, Vol. 83 No. 2, pp. 275-300.

Tomlinson, M. (2008), “'The degree is not enough': students' perceptions of the role of higher education credentials for graduate work and employability", British Journal of Sociology of Education, Vol. 29 No. 1, pp. 49-61. 
Van der Heijde, C.M. and Van der Heijden, B.IJ.M. (2006), "A competence-based and multidimensional operationalization and measurement of employability", Human Resource Management, Vol. 45 No. 3, pp. 449-476.

Van der Heijde, C.M. and Van der Heijden, B.IJ.M. (2014), "Employability and social innovation: the importance of and interplay between transformational leadership and personality", in Bondarouk, T. and Olivas-Luján, M.R. (Eds), Human Resource Management, Social Innovation and Technology, Vol. 14, Emerald Group Publishing Limited, pp. 55-72, available at: https://emeraldinsight.com/doi/full/10.1108/S1877-636120140000014009

Moderating role of LMX and proactive coping

Van der Heijden, B.I.J.M. and Bakker, A.B. (2011), "Toward a mediation model of employability enhancement: a study of employee-supervisor pairs in the building sector", Career Development Quarterly, Vol. 59 No. 3, pp. 232-248.

Van der Heijden, B.I.J.M. and De Vos, A. (2015), "Sustainable careers: introductory chapter”, in De Vos, A. and Van der Heijden, B.I.J.M. (Eds), Handbook of Research on Sustainable Careers, Edward Elgar Publishing, Cheltenham and Northampton, MA, pp. 1-19.

Van der Heijden, B.I.J.M., Gorgievski, M.J. and De Lange, A.H. (2016), "Learning at the workplace and sustainable employability: a multi-source model moderated by age", European Journal of Work and Organizational Psychology, Vol. 25 No. 1, pp. 13-30.

Van der Heijden, B.I.J.M., Boon, J., Van der Klink, M. and Meijs, E. (2009), "Employability enhancement through formal and informal learning: an empirical study among Dutch non-academic university staff members", International Journal of Training and Development, Vol. 13 No. 1, pp. 19-37.

Van der Heijden, B.I.J.M., De Lange, A.H., Demerouti, E. and Van der Heijde, C.M. (2009), "Age effects on the employability-career success relationship", Journal of Vocational Behavior, Vol. 74 No. 2, pp. 156-164.

Van der Heijden, B.I.J.M., Van Vuuren, T.C.V., Kooij, D.T.A.M. and De Lange, A.H. (2015), “Tailoring professional development for teachers in primary education: the role of age and proactive personality", Journal of Managerial Psychology, Vol. 30 No. 1, pp. 22-37.

Van der Heijden, B.I.J.M., Scholarios, D., Van Der Schoot, E., Jedrzejowicz, P., Bozionelos, N. and Epitropaki, O., Indic@tor Study Group (2010), "Supervisor-subordinate age dissimilarity and performance ratings: the buffering effects of supervisory relationship and practice", The International Journal of Aging and Human Development, Vol. 71, pp. 231-258.

Van der Klink, M., Van der Heijden, B.I.J.M., Boon, J. and Williams van Rooij, S. (2014), "Exploring the contribution of formal and informal learning to academic staff member employability", Career Development International, Vol. 19 No. 3, pp. 337-356.

Van Emmerik, H., Jawahar, I.M., Schreurs, B. and De Cuyper, N. (2011), "Social capital, team efficacy and team potency: the mediating role of team learning behaviors", Career Development International, Vol. 16 No. 1, pp. 82-99.

Van Harten, J., Knies, E. and Leisink, P. (2016), “Employer's investments in hospital workers' employability and employment opportunities", Personnel Review, Vol. 45 No. 1, pp. 84-102.

Vanhercke, D., De Cuyper, N., Peeters, E. and De Witte, H. (2014), "Defining perceived employability: a psychological approach”, Personnel Review, Vol. 43 No. 4, pp. 592-605.

Veld, M., Semeijn, J. and Van Vuuren, T. (2015), "Enhancing perceived employability", Personnel Review, Vol. 44 No. 6, pp. 866-882.

Veld, M., Van der Heijden, B.I.J.M. and Semeijn, J.H. (2016), "Home-to-work spillover and employability among university employees", Journal of Managerial Psychology, Vol. 31 No. 8, pp. 1280-1296.

Veth, K.N., Emans, B.J., Van der Heijden, B.I.J.M., Korzilius, H.P. and De Lange, A.H. (2015), "Development (f)or maintenance? An empirical study on the use of and need for HR practices to retain older workers in health care organizations", Human Resource Development Quarterly, Vol. 26 No. 1, pp. 53-80.

VSNU (2015), "Ratio of permanent to temporary staff", available at: www.vsnu.nl/en_GB/f_c_ verhouding_vast_tijdelijk.html (accessed September 21, 2015). 
CDI
Wang, H., Law, K.S., Hackett, R.D., Wang, D. and Chen, Z.X. (2005), "Leader-member exchange as a mediator of the relationship between transformational leadership and followers' performance and organizational citizenship behavior", Academy of Management Journal, Vol. 48 No. 3, pp. 420-432.

Weiss, H.M. (1990), "Learning theory and industrial and organizational psychology", in Dunnette, M.D. and Hough, L.M. (Eds), Handbook of Industrial and Organizational Psychology, Vol. 1, Consulting Psychologists Press, Palo Alto, CA, pp. 171-221.

Yizhong, X., Baranchenko, Y., Lin, Z., Lau, C.K. and Ma, J. (2019), "The influences of transformational leadership on employee employability: evidence from China”, Employee Relations, Vol. 41 No. 1, pp. 101-118.

\section{Corresponding author}

Beatrice Van der Heijden can be contacted at: B.vanderHeijden@fm.ru.nl 